\title{
Effect of Meal Replacement Therapy on Body Weight and Glycemic Control in Obese Type 2 Diabetes Adults: Asian Experiences
}

Gew SOON PENG'1, Mohd Yusof BARAKATUN-NISAK'1, Mat Daud ZULFITRI 'AZUAN'1 , Tay SOOK HUI ${ }^{1}$ and Embong MUSTAFA

${ }^{1}$ Department of Nutrition and Dietetic, Faculty of Medicine and Health Sciences, Universiti Putra Malaysia. ${ }^{2} D^{\prime}$ Centers (NADI)-Diabetes Resource Centre, Malaysia.

\section{Background:}

Excess body weight is a common manifestation in adults with type 2 diabetes (T2D), which associated with non-optimum glycemic control. While the use of meal replacement therapy (MRT) to induce weight loss and improve glycemic control is recommended as part of the medical nutrition therapy (MNT), its feasibility remains unclear especially from the Asian perspective.

Aim:

This study aims to determine the effect of 12-weeks of MRT on body weight and glycemic control in obese T2D adults.

\section{Method:}

We recruited a total of 32 participants from National Diabetes Institute (NADI). They were randomly assigned to receive the MRT $(n=16)$ or conventional dietary intervention $(n=16)$ for 12 -weeks study. Table 1 shows the similarities and differences in the structure of MRT and conventional intervention. MRT and conventional participants received the MNT from a researcher and a NADI's dietitian, respectively. The prescriptions designed as iso-caloric. Participants in the MRT group were asked to replace their two meals with two meal replacements in a day.

\begin{tabular}{|c|c|c|}
\hline & MRT & Conventional \\
\hline $\begin{array}{l}\text { Daily Energy Intake } \\
\text { (kcal/day) }\end{array}$ & 1200 (100\%) & 1200 (100\%) \\
\hline \multicolumn{3}{|l|}{ Macronutrients } \\
\hline Carbohydrate (g) & $130(40 \%)$ & $150(50 \%)$ \\
\hline Protein $(\mathrm{g})$ & $86(30 \%)$ & $56(20 \%)$ \\
\hline Fat (g) & $40(30 \%)$ & $37(30 \%)$ \\
\hline \multirow[t]{3}{*}{ Nutritional Strategies } & $\begin{array}{l}\text { Received MRT and healthy } \\
\text { eating advice from researcher }\end{array}$ & $\begin{array}{l}\text { Received MNT advice } \\
\text { from NADI's dietitian }\end{array}$ \\
\hline & Weight loss orientation & $\begin{array}{c}\text { Carbohydrate-controlled } \\
\text { orientation }\end{array}$ \\
\hline & $\begin{array}{c}2 \text { meals are liquid products of } \\
\text { MRT, } 1 \text { meal is solid food and } \\
1 \text { snack }\end{array}$ & $\begin{array}{l}3 \text { meals are solid food } \\
\text { and } 1 \text { snack }\end{array}$ \\
\hline PAL & \multicolumn{2}{|c|}{ Gradual increase with a goal of $150 \mathrm{~min} /$ week } \\
\hline Medication\# $\#$ & \multicolumn{2}{|c|}{ Medication changes by physician or endocrinologist } \\
\hline
\end{tabular}

Body weight and glycemic control were assessed at baseline, 6 and 12-weeks of the study. Data presented based on intention-to-treat (ITT) analysis.

Results:

A total of 27 participants completed the study providing $84.4 \%$ responses rate (MRT $=14$, 87.5\%; Conventional $=13,81.3 \%$ ). Baseline characteristics (mean; age $=46.4 \pm 8.2$ years old, female $=34.4 \%$, body mass index $(\mathrm{BMI})=31.8 \pm 4.9 \mathrm{~kg} / \mathrm{m}^{2}, \mathrm{HbA1c}=8.8 \pm 1.5 \%$, duration of $\mathrm{T} 2 \mathrm{D}=5.0 \pm 4.1$ years) were comparable between groups (Table 2).

Table 2: Baseline Characteristics of Participants

\begin{tabular}{|c|c|c|c|c|c|c|}
\hline \multicolumn{2}{|c|}{ Characteristics } & \multicolumn{2}{|c|}{ MRT $(n=16)$} & \multicolumn{2}{|c|}{$\begin{array}{c}\text { Conventional } \\
(n=16)\end{array}$} & \multirow{3}{*}{$\begin{array}{c}\begin{array}{c}\text { Between } \\
\text { Groups } \\
\text { p-Value }\end{array} \\
0.447\end{array}$} \\
\hline & & $\%$ & $\mathbf{n}$ & $\%$ & $\mathbf{n}$ & \\
\hline Age (years old) & & \multicolumn{2}{|c|}{$45.25 \pm 8.35$} & \multicolumn{2}{|c|}{$47.50 \pm 8.15$} & \\
\hline \multirow[t]{2}{*}{ Sex } & Male & 35 & 11 & 31 & 10 & 0.721 \\
\hline & Female & 15 & 5 & 19 & 6 & \\
\hline \multirow[t]{3}{*}{ Education } & Primary & 3 & 1 & 3 & 1 & 0.073 \\
\hline & Secondary & 19 & 6 & 37 & 12 & \\
\hline & Tertiary & 28 & 9 & 10 & 3 & \\
\hline \multicolumn{2}{|c|}{ Diabetes Duration (years) } & \multicolumn{2}{|c|}{$5.30 \pm 4.61$} & \multicolumn{2}{|c|}{$4.60 \pm 3.54$} & 0.637 \\
\hline \multirow[t]{4}{*}{ Types of OAD } & Diet & 9 & 3 & 13 & 4 & 0.440 \\
\hline & Single & 28 & 9 & 19 & 6 & \\
\hline & Dual & 13 & 4 & 9 & 3 & \\
\hline & Triad & 0 & 0 & 9 & 3 & \\
\hline \multirow[t]{3}{*}{ Income (monthly) } & $\leq$ USD 480 & 19 & 6 & 25 & 8 & 0.426 \\
\hline & > USD 480 & 13 & 4 & 12 & 4 & \\
\hline & $\geq$ USD 1200 & 19 & 6 & 12 & 4 & \\
\hline
\end{tabular}

At 12 -weeks, MRT group had a significant reduction in body weight $(83.3 \pm 13.0 \mathrm{~kg}, \Delta$ baseline $=-3.5 \pm 0.5 \mathrm{~kg})$ than the conventional group $(87.2 \pm 20.8 \mathrm{~kg}, \Delta$ baseline $=-1.1 \pm$ $2.4 \mathrm{~kg} ; \mathrm{p}<0.01$ ) (Table 3).

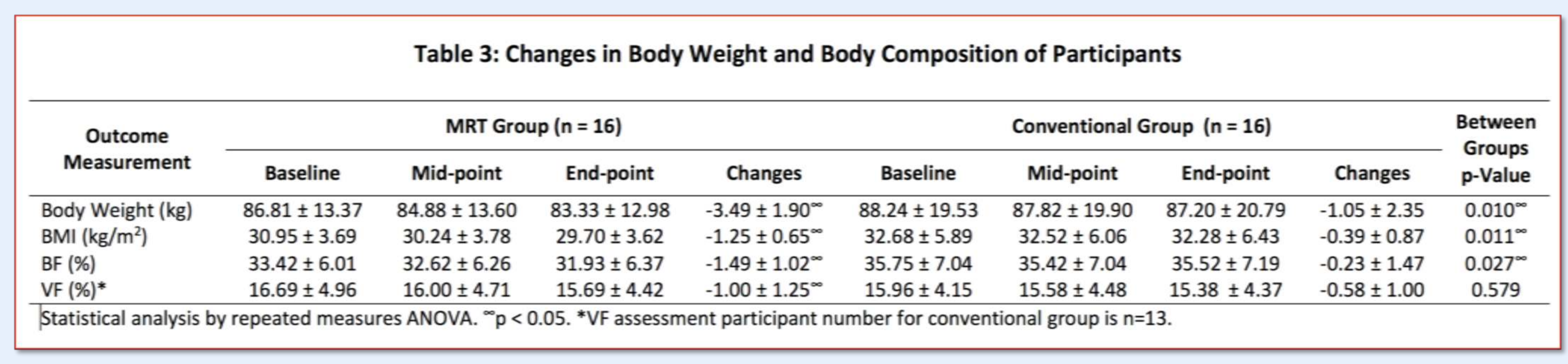

The percentage of weight loss in MRT $(-4.1 \pm 2.1 \%)$ was significantly larger than the conventional group $-1.4 \pm 2.5 \% ; p<0.01$ ) (Figure 1). A significant improvement in BMI and percentage of body fat were also observed in MRT group as compared to the conventional group.

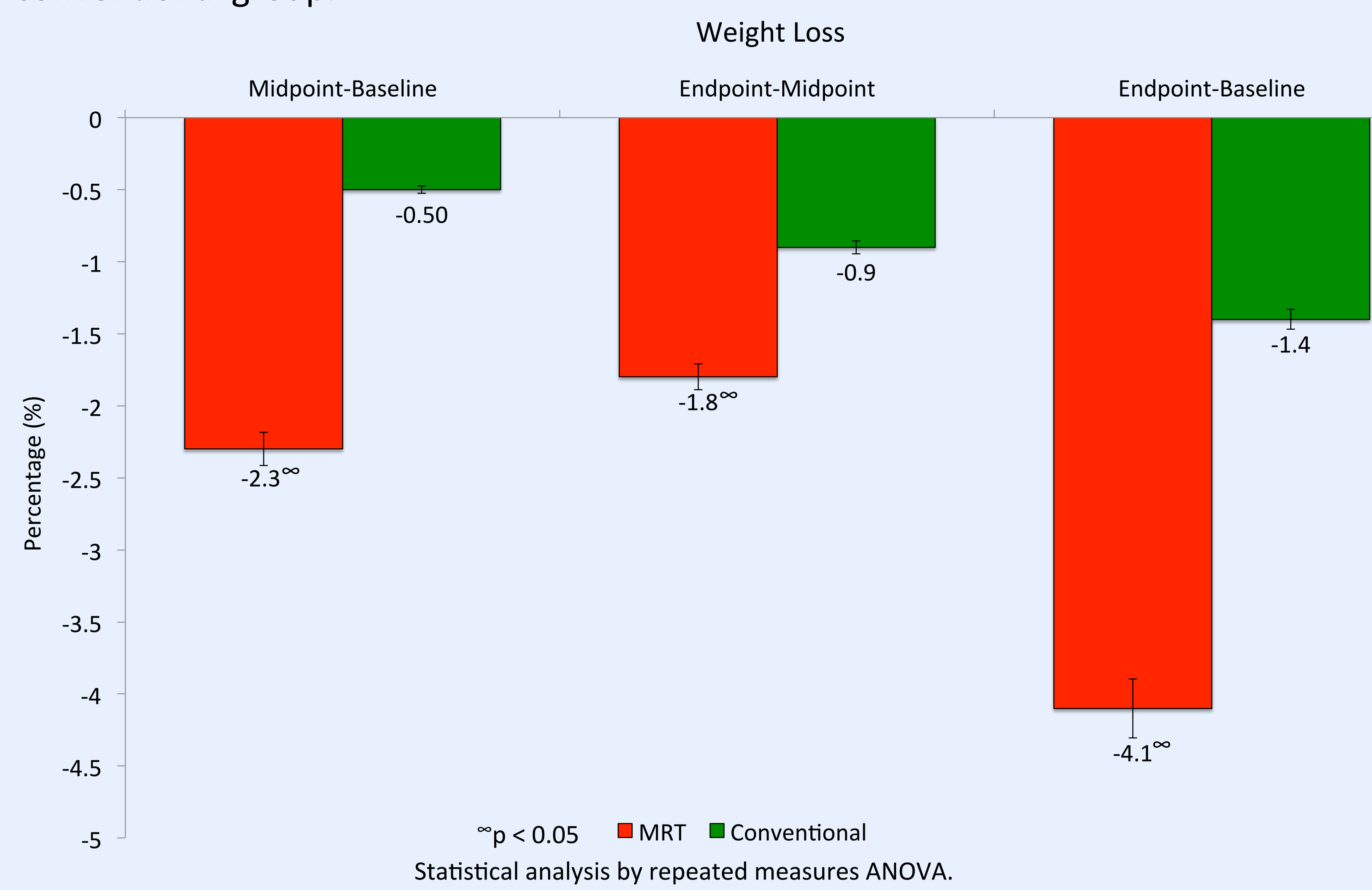

Figure 1: Changes in Percentage of Weight Loss at End-point

Although generally the differences between groups in $\mathrm{HbA1c}$ were not significant, we attained significant differences between both groups $(p=0.006)$ in $\mathrm{HbA} 1 \mathrm{c}$ after excluding confounders effect of the participants who had changed the types of OAD. Within MRT group had reduced $\mathrm{HbA} 1 \mathrm{c}$ level from $9.1 \pm 1.5 \%$ at baseline to $7.9 \pm 1.2 \%$ at 12 weeks ( $\Delta$ baseline $=-1.1 \% ; p<0.01$ ), which were not observed in the conventional group $($ baseline $=8.5 \pm 1.5 \% ; 12$ weeks $=8.0 \pm 1.1 \% ; \Delta$ baseline $=-0.5 \% ; p=0.11$ ) (Figure 2).

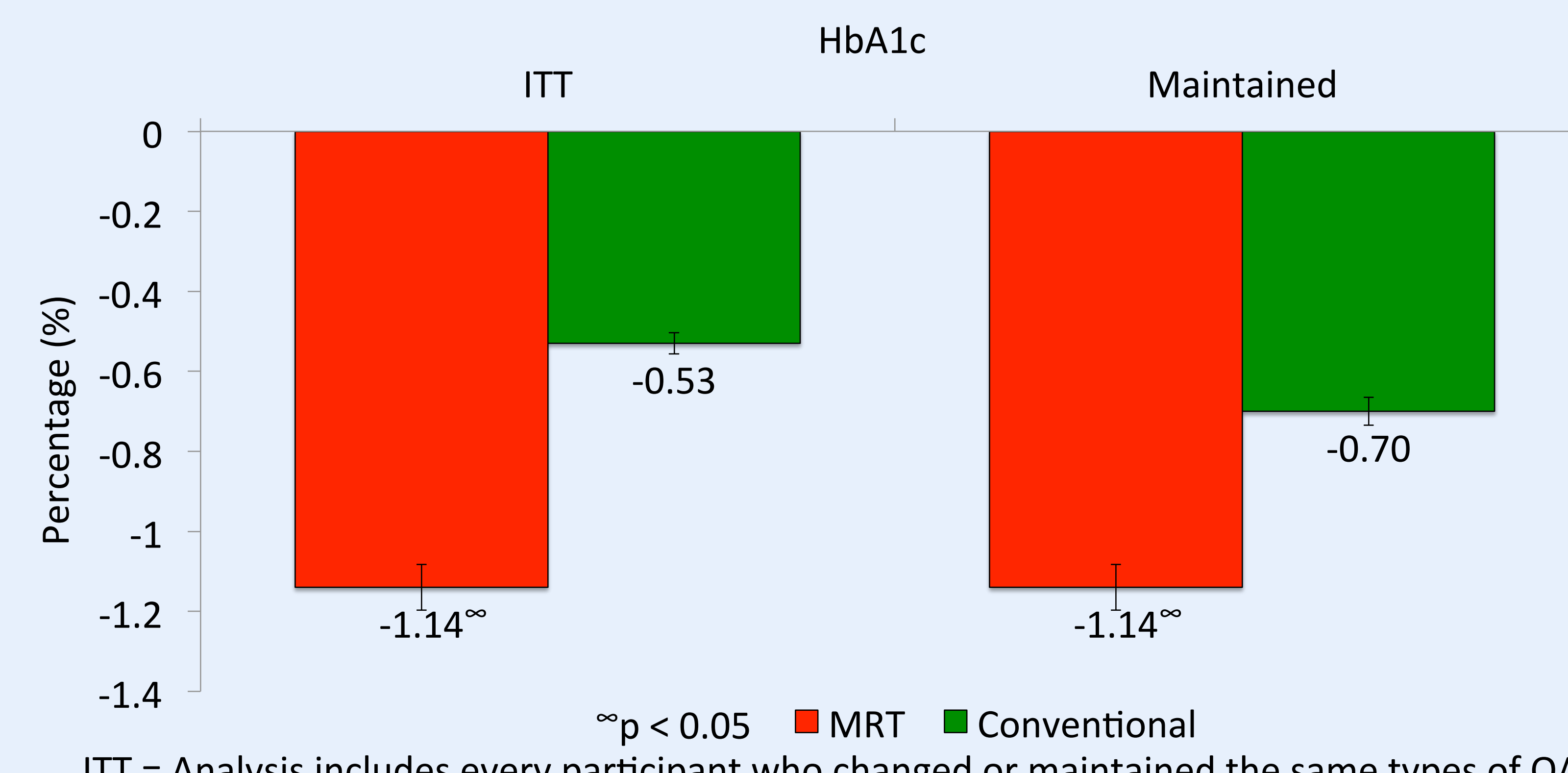

ITT = Analysis includes every participant who changed or maintained the same types of OAD. Maintained = Analysis include participants who maintained the same types of OAD. Statistical analysis by repeated measures ANOVA.

Figure 2: Changes in HbA1c on ITT (MRT, $n=16 ; S D T, n=16$ ) and Participants who Maintained the Same Types of OAD (MRT, $n=16$; SDT, $n=12$ ) Analysis at End-point

About $72.5 \%$ of the participants in the MRT group adhered to meal-replacement intervention.

Conclusion:

- The used of meal replacement therapy induces larger weight loss, BMI and percentage of body fat than the conventional dietary intervention at 12-weeks.

- In general, the improvement in $\mathrm{HbA1c}$ was not significant between groups, but removing confounding effect of diabetes medication had produced significant in differences between groups. Within the MRT group was evident in HbA1c reduction (>1\%).

- The high adherence rate demonstrated the feasibility of meal replacement implementation in Asian adults with type 2 diabetes. 